\title{
Growth (without Multiplication) of Mycobacterium lepraemurium in Cell-free Medium
}

\author{
By P. D'ARCY HAR'T AND R. C. VALENTINE \\ The National Institute for Medical Research, Mill Hill, London, N.W. 7
}

(Received 1 November 1962)

\section{SUMMARY}

Leprosy bacilli have not been cultivated with certainty in any cell-free medium, but the medium now described consistently supported considerable elongation of the organisms of murine leprosy (Mycobacterium lepraemurium), though without evidence of multiplication. The mean length of the bacilli doubled in about the generation time obtaining in host cells (7-14 days) and quadrupled before the bacilli became degenerate after about 2 months. The obligate acidity and other factors concerned in this growth were investigated, and are discussed in relation to the problem of the extracellular cultivation of leprosy bacilli.

\section{INTRODUCTION}

In the present context, 'growth' of a bacterium is defined as a gradual 'increase in bulk by the process of organic life', without this necessarily being accompanied by multiplication. (The distinction is illustrated by Nicolay (1585): 'Great bushes, and wilde brambles, which in process of time... were so growen and multiplyed'.) A cell-free medium is defined as one without intact tissue cells.

Continuous intracellular multiplication of Mycobacterium lepraemurium, the rat leprosy bacillus (used often as a laboratory model in leprosy studies), has recently been obtained in cultures of rat fibroblasts (Rees \& Garbutt, 1962), but this species has never been shown unequivocally to multiply at all in any cell-free nutrient medium (Eddy, 1937; Gray, 1952). We have similarly failed with many such media, and have moreover found with the electron microscope that most of the bacilli are degenerate (dead) within $2-3$ weeks at $37^{\circ}$. However, by adding sucrose to a concentration of $10 \%$ to a liquid medium (modified from that of Dubos \& Davis, 1946) that is used in these laboratories for subsurface culture of Mycobacterium tuberculosis, Hart \& Valentine (1960) obtained an increase in bacillary length in $M$. lepraemurium and a delay in its degeneration. We now report the further development of this work, which provides evidence of a living process, even though no multiplication has been detected.

\section{Source of the bacilli}

\section{METHODS}

The bacilli were provided by Dr R. J. W. Rees and his co-workers:

(a) From infected mice. The liver of a mouse of the albino $\mathbf{P}$ strain which had been inoculated intravenously 4-6 months previously with Mycobacterium lepraemurium (Douglas strain), and which had usually received suramin to enhance the infection, 
was homogenized (see Hart, Rees \& Valentine, 1962a), and the bacilli partly freed from the tissue components by the method of Garbutt, Rees \& Barr (1962) and then suspended in physiological saline solution containing $1 \%$ albumin (bovine plasma fraction $\mathrm{V}$, Armour), to give about $2 \times 10^{9}$ acid-fast bacilli $/ \mathrm{ml}$, , as counted by the method of Hart \& Rees (1960). The organisms were well dispersed and predominantly single.

(b) From infected tissue cultures. A suspension, in Hanks balanced salt solution, of rat fibroblasts containing bacilli of $M$. lepraemurium (Garbutt et al. 1962) was centrifuged at $1200 \mathrm{rev} . / \mathrm{min}$. $(250 \mathrm{~g})$ for $5 \mathrm{~min}$. to deposit the tissue cells, which were concentrated by removing an appropriate amount of the supernatant fluid. In some experiments the bacilli were released from the cells by exposure to ultrasonic vibration $(400 \mathrm{kc}$. $/ \mathrm{sec}$. supplied by a $500 \mathrm{~W}$. generator) for $1 \mathrm{~min}$. In the present work tissue culture-grown bacilli were used much less frequently than bacilli from infected mouse livers. Unless otherwise stated, the infected mouse liver was the source for inoculation into cell-free medium.

Table 1. Final concentrations of ingredients of the present medium for studying elongation of Mycobacterium lepraemurium bacilli

\begin{tabular}{ll}
\multicolumn{1}{c}{ Ingredient } & $\%(w / v)$ \\
Casamino acids (Difco) & $\mathbf{1 \cdot 6}$ \\
Asparagine & $\mathbf{0 . 7 5}$ \\
$\mathrm{Na}_{2} \mathrm{HPO}_{4}$ & $0 \cdot 14$ \\
$\mathrm{KH}_{2} \mathrm{PO}_{4}$ & $0 \cdot 06$ \\
Sodium citrate & $0 \cdot 08$ \\
$\mathrm{MgSO}_{4}, 7 \mathrm{H}_{2} \mathrm{O}$ & $0 \cdot 03$ \\
Glycerol & $\mathbf{2 \cdot 9}$ \\
Albumin & $\mathbf{0 \cdot 1 8}$ \\
Sucrose & $\mathbf{7 \cdot 4}$
\end{tabular}

* $0.15 \%$ when the inoculum was from tissue culture.

\section{Present medium}

The basal medium was composed of: Difco (Bacto) 'Casamino acids' (certified), 29 g.; $L$-asparagine monohydrate, 13.5 g.; anhydrous $\mathrm{Na}_{2} \mathrm{HPO}_{4}, 2.5$ g.; $\mathrm{KH}_{2} \mathrm{PO}_{4}$, 1.0 g.; trisodium citrate, 1.5 g.; $\mathrm{MgSO}_{4}, 7 \mathrm{H}_{2} \mathrm{O}, 0.6$ g.; glycerol, $53 \mathrm{ml}$.; de-ionized water to $1000 \mathrm{ml}$.; adjusted with $\mathrm{HCl}$ or $\mathrm{NaOH}$ to $\mathrm{pH} 6 \cdot 2$ or as required; autoclaved at $115^{\circ}$ for $20 \mathrm{~min}$. This autoclaved solution was distributed in $4.5 \mathrm{ml}$. amounts into $1 \mathrm{oz}$. (28 ml.) screw-capped bottles, to which were added $0.25 \mathrm{ml}$. of $5 \%$ aqueous solution of albumin (fraction V) sterilized by filtration; $1.2 \mathrm{ml}$. of autoclaved $50 \%$ $(\mathrm{w} / \mathrm{v})$ sucrose solution; solutions of any test substances; water to $7.9 \mathrm{ml}$; $0.2 \mathrm{ml}$. of the bacillary suspension from mouse liver homogenate or tissue culture, giving a final total volume of $8.1 \mathrm{ml}$, containing about $5 \times 10^{7}$, or $10^{6}-10^{7}$, bacilli $/ \mathrm{ml}$., respectively. The final concentrations of the ingredients in the complete medium are shown in Table 1 ; in addition a small amount of liver or fibroblast tissue from the inoculum was inevitably present.

\section{Assessment of growth of bacilli in medium}

A bacillary suspension in the medium was immediately fixed by adding formaldehyde to a concentration of $1 \%$; this served as a sample of the inoculum (for a base 
line) and was stored at $4^{\circ}$ (no significant change in the length of the bacilli occurred during storage). Other suspensions in the same medium were incubated, at $37^{\circ}$ unless otherwise stated, for periods up to 2 months and were then similarly fixed. The inoculum sample and the incubated suspensions were diluted $1 / 8$ in water (to decrease the sucrose concentration) and then centrifuged at $2000 \mathrm{~g}$ for $30 \mathrm{~min}$. in $8 \mathrm{ml}$. Pyrex tubes. The deposited bacilli were dispersed in about $0 \cdot 1 \mathrm{ml}$. of supernatant fluid by exposure to ultrasonic vibration $(400 \mathrm{kc} . / \mathrm{sec}$.) for $1 \mathrm{~min}$.

Samples of the deposits were examined in the electron microscope, adjusted to a magnification of 10,000 by means of standard spheres (diam. $0 \cdot 26 \mu$ ) of polystyrene latex. A series of concentric circles, the circumferences of which were spaced by $0.5 \mathrm{~cm}$., drawn on the fluorescent screen on which the final image was seen, allowed the lengths of the bacilli to be estimated to the nearest $0 \cdot 1 \mu$. The lengths of 100 or more bacilli from each sample were measured in this way, and the frequency distributions of lengths and their means calculated. At the same time the proportion of bacilli which appeared degenerate (McFadzean \& Valentine, 1959) was estimated. In addition, the bacillary deposits were stained by the Ziehl-Neelsen method and examined with the light microscope; a grading of length was made without formal measurement, and, using the modified stain described by Rees \& Valentine (1962), the presence of degenerate bacilli was assessed. (Unless otherwise stated, bacillary lengths and proportions degenerate refer to the results obtained with the electron microscope.)

\section{RESULTS}

Optimal conditions for elongation of the bacilli of Mycobacterium lepraemurium

The nutrient medium used by Hart \& Valentine (1960) required a high concentration of sucrose (or glucose) in order to obtain substantial lengthening of the bacilli. However, the results were irregular. They were somewhat better when $\mathrm{Fe}^{3+}$ was added to $15 \mu \mathrm{g} . / \mathrm{ml}$. and $\mathrm{Mg}^{2+}$ was increased to $14 \mathrm{mM}$ (Hart, Rees \& Valentine, $1962 b$ ); but these additions were not necessary with the present medium. In the latter, the Casamino acids were increased 6 and the asparagine 25 times; the sucrose was $7 \cdot 4 \%$; and the solution had a specified acidity (see below). Elongation was then more rapid, more uniformly distributed in the bacterial population, and reached a higher final figure; and the results were regularly reproducible.

The acidity of the medium was critical for elongation to occur. Figure 1 shows the mean length and the degree of degeneration of the bacilli, obtained from infected mouse liver, after 17 days of incubation at $37^{\circ}$ in the medium at different initial $\mathrm{pH}$ values (the $\mathrm{pH}$ value remained stable during this period). The greatest elongation (mean length nearly $4 \mu$ ) occurred around pH 6.0-6.4, with a rather sharp peak; and there was virtually none (mean length about $2 \mu$ compared with $1 \cdot 8 \mu$ in the original inoculum) at $\mathrm{pH} 7 \cdot 2$ and more, or at $\mathrm{pH} 5.0$ and less. The curve for the proportion of bacilli which were degenerate (assessed by electron microscopy) was nearly a mirror-image of that for lengthening; the majority were degenerate

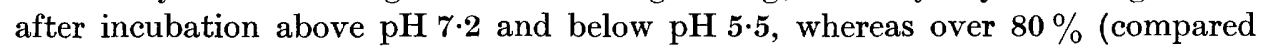
with over $90 \%$ in the original inoculum) were still not degenerate at $\mathrm{pH} \mathrm{6.4.} \mathrm{It} \mathrm{has}$ not been possible to separate the association between acidity and lengthening and that between acidity and decreased degeneration; the optimum $\mathrm{pH}$ value was about the same for both and, moreover, all alterations so far made to the medium which 
resulted in abolition of the elongation at $\mathrm{pH} 6.2$ were accompanied also by degeneration similar to that seen at neutrality.

On the basis of these findings, a value of about $\mathrm{pH} 6 \cdot 2$ was specified for the medium when elongation was desired, and of about $\mathrm{pH} 7 \cdot 2$ when it was not. The progress, in a typical experiment, of elongation and degeneration of the bacilli (from infected

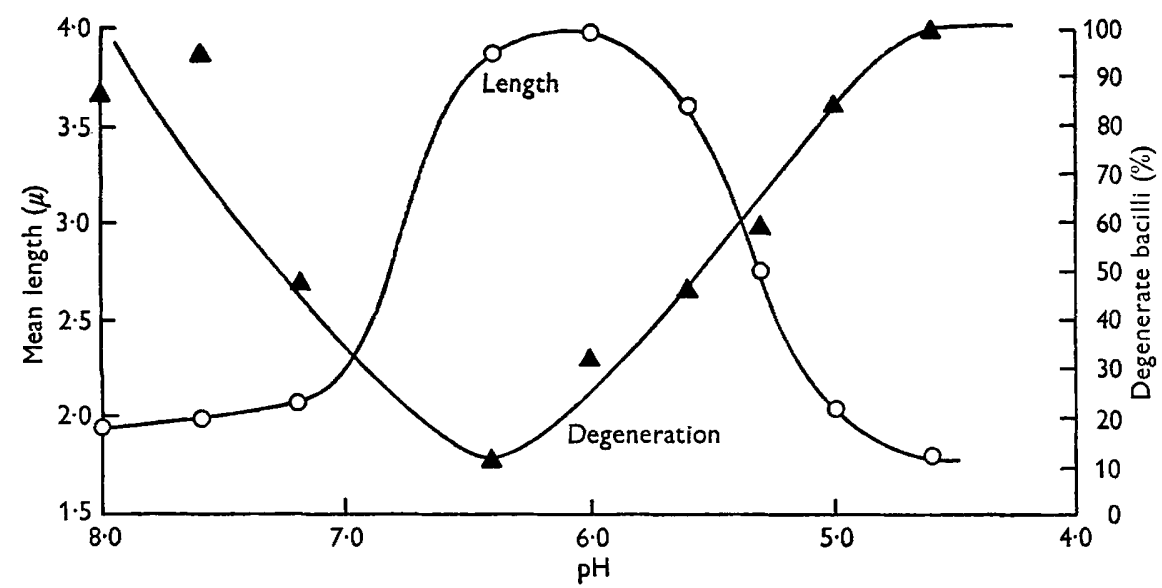

Fig. 1. The lengths $(O)$ and proportions degenerate $(\Delta)$ of Mycobacterium lepraemurium organisms after incubation at $37^{\circ}$ for 17 days in the medium adjusted with $\mathrm{HCl}$ or $\mathrm{NaOH}$ to different $\mathrm{pH}$ values. The mean length of the bacilli in the inoculum was $1.8 \mu$ and less than $5 \%$ were degenerate.

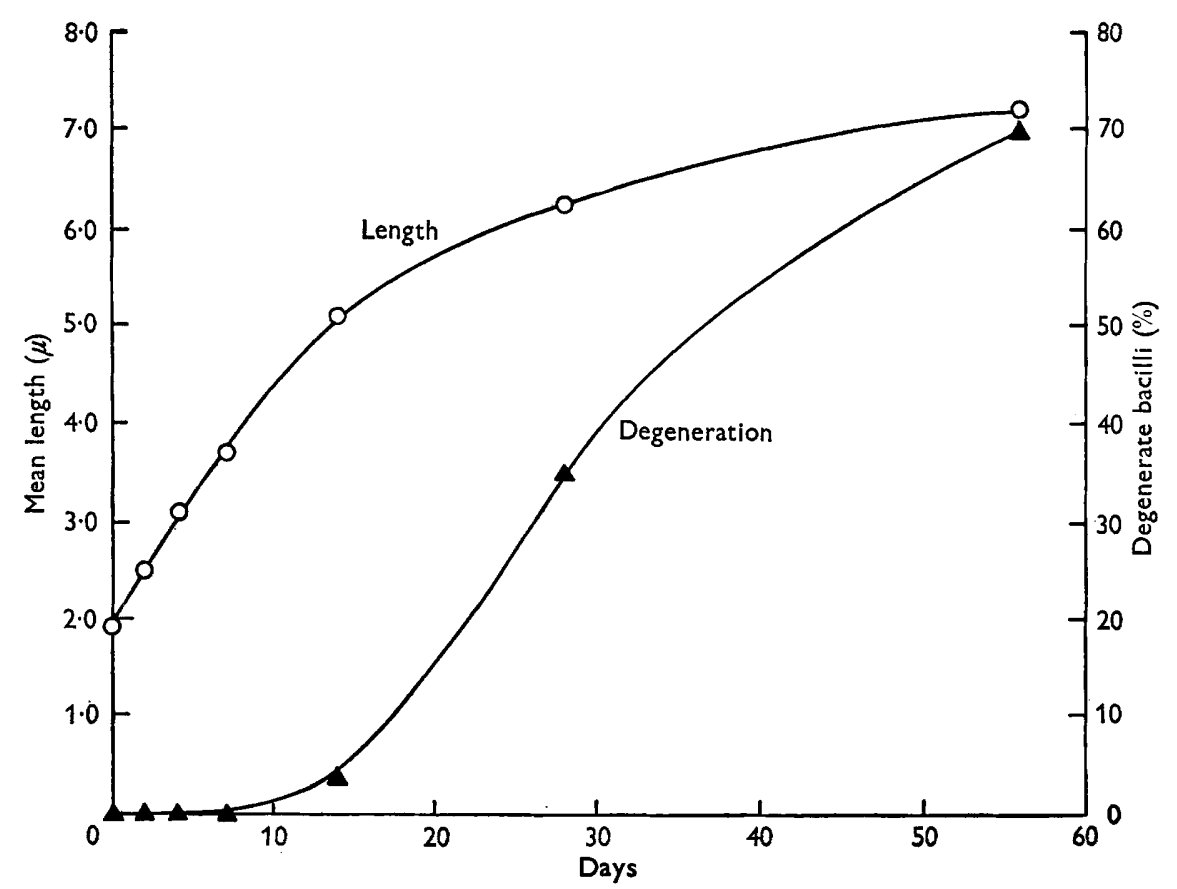

Fig. 2. The lengths (O) and proportions degenerate (A) of Mycobacterium lepraemurium organisms after different periods of incubation at $37^{\circ}$ in the medium at $\mathrm{pH} \mathrm{6.0.}$ 
mouse liver) during 2 months of incubation at $37^{\circ}$ in the medium at $\mathrm{pH} 6.0$ is shown in Fig. 2. Some lengthening was evident by 2 days. The mean length of $1.9 \mu$ in the original inoculum doubled by 7 days; after between 7 and 14 days the rate of increase gradually decreased, and the mean length at 60 days was $7 \cdot 1 \mu$. The proportion of organisms which were degenerate (initially less than $5 \%$ ) was still less than $10 \%$ at $7-14$ days; it then increased gradually, reaching $35 \%$ by 30 days and $70 \%$ by 60 days, by which time elongation had virtually ceased. Hence degeneration, already marked at 2 weeks at $\mathrm{pH}$ values unfavourable to elongation (Fig. 1), was postponed but not avoided under these optimum conditions.

The frequency distribution of lengths of bacilli in the original inoculum is compared (Table 2) with that after incubation for 17 days in the medium. Initially, only $4 \%$ of bacilli measured more than $3 \mu$ and $32 \%$ more than $2 \mu$; after the incubation the corresponding percentages were $62 \%$ and $87 \%$. The increase in mean length is clearly due to a general shift and not merely to a few very long bacilli.

Table 2. Length distribution of Mycobacterium lepraemurium organisms before and after incubation for 17 days at $37^{\circ}$ in the medium at $\mathrm{pH} 6 \cdot 0$

\begin{tabular}{ccc} 
Length & \multicolumn{2}{c}{$\%{ }^{\text {bacilli }}$} \\
Initially & After 17 days \\
$0-1$ & 0 & 0 \\
$1-2$ & 68 & 13 \\
$2-3$ & 28 & 25 \\
$3-4$ & 4 & 25 \\
$4-5$ & 0 & 17 \\
$5-6$ & 0 & 8 \\
$6-7$ & 0 & 4 \\
$7-8$ & 0 & 4 \\
$8-9$ & 0 & 2 \\
$9-10$ & 0 & 2
\end{tabular}

The necessary constituents of the medium were investigated further, first, by adding albumin and sucrose in the same concentrations to phosphate buffer $\mathrm{pH} 7 \cdot 3$ and $6 \cdot 2$, the phosphate being finally $M / 50$ and $M / 125$ (that in the medium was $M / 70$ ). After incubation for $\mathbf{1 7}$ days in these four buffer mixtures, there was no appreciable increase in average length of the bacilli at either $\mathrm{pH}$ value, whereas the complete medium showed none also at the higher $\mathrm{pH}$ value, but more than trebling of initial mean length at the lower $\mathrm{pH}$ value. The proportion of organisms which were degenerate was $5 \%$ in the inoculum, $60 \%$ or more in all the four buffer mixtures after incubation for 17 days, as compared with only $10 \%$ at $\mathrm{pH} 6.2$ in the complete medium. Next, to a similar buffer mixture at $\mathrm{pH} 6.2$ (phosphate $\mathrm{m} / 70$; albumin and sucrose as before) glycerol was added to $2.9 \%(\mathrm{w} / \mathrm{v})$, as in the complete medium. Some elongation was now evident after incubation (though less than in the complete medium), whereas there was again none in the buffer mixture without glycerol.

The microscopic appearances of Mycobacterium lepraemurium in the conditions described are illustrated. Plate 1 shows, by electron microscopy: a normal bacillus from infected mouse liver ( $\mathrm{Pl} .1$, fig. 1); a degenerate bacillus such as is produced by incubation for 2 or more weeks in phosphate buffer, or in the complete medium at $\mathrm{pH} \mathrm{7.2} \mathrm{(Pl.} \mathrm{1,} \mathrm{fig.} \mathrm{2);} \mathrm{a} \mathrm{long} \mathrm{apparently} \mathrm{healthy} \mathrm{bacillus} \mathrm{as} \mathrm{produced} \mathrm{in} \mathrm{the}$ 
medium at $\mathrm{pH} 6 \cdot 2$ (Pl. 1, fig. 3); a long bacillus which has eventually degenerated (Pl. 1, fig. 4). Plate 2 shows, by light microscopy : bacilli from mouse liver immediately after inoculation into the medium (Pl. 2, fig. 5), and also the bacilli after incubation for 17 days at $\mathrm{pH} 6.2$ (Pl. 2, fig. 6) and at $\mathrm{pH} \mathrm{7.4} \mathrm{(Pl.} \mathrm{2,} \mathrm{fig.} \mathrm{7);} \mathrm{bacilli} \mathrm{in} \mathrm{tissue}$ culture cells as inoculated into the medium (Pl. 2, fig. 8), and their appearances after incubation for 14 days at $\mathrm{pH} 6 \cdot 1$ (Pl. 2, figs. 9, 10). In the light microscope, long bacilli in the early stages showed a characteristic beaded appearance of the stained material which made assessment of degree of degeneration more difficult than in the electron microscope; degeneration in short bacilli, as well as in long bacilli at a later stage, was easier to assess from the gross irregularity of the stained material.

\section{Increase in weight of the bacilli}

The dry weights of the bacilli could be estimated from the electron micrographs by using electron-scattering theory (Valentine, 1962). In a typical experiment, the mean dry weights so obtained before and after 2 weeks of incubation in the medium at acid reaction were: bacillus inoculated into the medium $=5.9 \times 10^{-11} \mathrm{mg}$; bacillus after incubation for 14 days in the medium $=12.0 \times 10^{-11} \mathrm{mg}$. During this 14-day period the mean length of the bacilli increased from $2 \cdot 1$ to $4 \cdot 6 \mu$, i.e. almost in the same proportion as the weight. In the same time there was usually a slight (c. $20 \%$ ) increase in the width of the bacilli.

\section{The effect of unfavourable environment on subsequent ability to elongate}

The bacilli were incubated in the medium for various periods at a $\mathrm{pH}$ value either too large or too small for elongation to occur; the $\mathrm{pH}$ value was then changed to the optimum $\mathrm{pH}$ range by adding acid or alkali. Thus, after 1 day at $\mathrm{pH} 7 \cdot 7$, followed by 2 weeks at $\mathrm{pH} 6 \cdot 0$, the bacilli lengthened moderately well, whereas when this change in $\mathrm{pH}$ value was made (from $\mathrm{pH} 7 \cdot 7$ or $7 \cdot 2$ to $\mathrm{pH} 6 \cdot 0$ ) after 1 week, they lengthened little or not at all. Similar results were obtained when 1 week at $\mathrm{pH} 4 \cdot 4$ or 4.8 was followed by 2 weeks at $\mathrm{pH} 6 \cdot 3$. On the other hand, organisms incubated in the medium at $\mathrm{pH} 6.2$ for 1 week, and then transferred to fresh medium at $\mathrm{pH} 6.2$ and 7.0 for a further 2 weeks, continued to lengthen at the lower $\mathrm{pH}$ value but not at the higher. Finally, bacilli which were incubated in phosphate buffer mixtures (see above) for 2 weeks, whether at $\mathrm{pH} 6 \cdot 2$ or $7 \cdot 3$, and then (when more than half were seen to be degenerate by microscopy) transferred to the

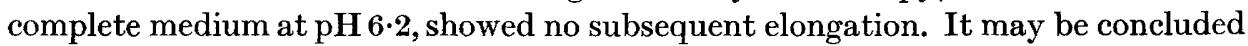
that, when the $\mathrm{pH}$ value or the composition of the medium was unfavourable to elongation, not only did degeneration (as seen by microscopy) rapidly ensue (see above), but the ability to lengthen when subsequently the $\mathrm{pH}$ value or the composition of the medium was made favourable was soon diminished and abolished.

The natural resistance of Mycobacterium lepraemurium to killing by alkali was tested by exposing a bacillary suspension (from infected mouse liver) in $\mathbf{0 . 5}$ or $0.05 \%$ albumin saline to $0.1 \mathrm{~N}$ or $0.02 \mathrm{~N}-\mathrm{NaOH}$ for $30 \mathrm{~min}$. at $35^{\circ}$, and washing the organisms, before inoculating them into the medium at $\mathrm{pH} 6 \cdot 2$. Resistance to mineral acid was tested by exposing a suspension in $0.025 \%$ albumin saline to $0 \cdot 1 \mathrm{~N}-\mathrm{HCl}$ for $2 \mathrm{hr}$. at $37^{\circ}$, neutralizing, and then inoculating into the medium at $\mathrm{pH} 6 \cdot 2$. In both cases the capacity for lengthening was still evident, though 
diminished. In this resistance, more particularly to acid, $M$. lepraemurium resembles $M$. tuberculosis, in which species this property is well known.

\section{The effect of temperature}

Bacilli were kept in medium at $42^{\circ}, 37^{\circ}, 34^{\circ}, 24^{\circ}$ and $4^{\circ}$ for a month. The elongation at $34^{\circ}$ was slightly less than at $37^{\circ}$, and there was none at the other temperatures. In another experiment samples of a bacillary suspension from infected mouse liver in the usual $1 \%$ albumin saline were kept at $37^{\circ}$ and $4^{\circ}$ for 14 days, samples being withdrawn periodically from each lot of suspension and inoculated into the medium at $\mathrm{pH} 6 \cdot 0$, which was then incubated for 14 days at $37^{\circ}$ and the bacilli examined for lengthening. Bacilli sampled from the $37^{\circ}$ suspension on days 0 and 2 showed lengthening to a similar and considerable degree in the medium, but those sampled at day 5 lengthened hardly at all. In contrast, bacilli from the $4^{\circ}$ suspension showed considerable lengthening when sampled up to day 8 , and a little when sampled on day 14.

\section{Tissue contamination}

Mycobacterium lepraemurium is intracellular in vivo, but the method of preparation of the bacillary suspensions from mouse liver breaks up the tissue cells. Thus electron and light microscopy have not revealed any intact liver cells in samples of bacilli examined either before or after incubation in the medium for 14 days. It was, nevertheless, conceivable that some few liver cells were necessary for elongation to occur. This was excluded by the finding that lengthening could occur after treatment with $\mathrm{NaOH}$ (p. 48), which decreased the total cold trichloracetic acidprecipitatable material of the liver in the final bacillary suspension by $80-90 \%$. Such digestion not only would have destroyed any whole cells but also would have removed most of the remaining cell fragments.

Towards further exclusion of an essential role of tissue cells, a suspension of Mycobacterium lepraemurium was specially freed from liver remnants by additional differential centrifugation, and then tested for bacillary elongation in the usual manner; this was found to be similar to that of a normal preparation of bacilli. With a similar object, bacilli from a tissue culture were released from the fibroblasts by ultrasonic vibration, and the suspension washed twice and resuspended in $1 \%$ albumin saline; again lengthening occurred.

Although it seems unlikely, therefore, that contaminating tissue played an essential part in the bacillary growth in the complete medium, it is possible that the residual liver in the preparations from mice contributed some of the nutritional requirements for growth.

\section{Stale medium}

Bacilli were incubated for 2 weeks in the complete medium at $\mathrm{pH} 6 \cdot 2$; the suspension was then centrifuged and fresh bacilli inoculated into the supernatant fluid, and incubation carried on for a further 2 weeks. In another experiment a fresh suspension was inoculated into the supernatant fluid from some of our earlier medium which had been in contact at $37^{\circ}$ with bacilli for 2 months. In both experiments the fresh bacilli lengthened in the old supernatant fluid. 'Staling' of the medium appeared therefore not to be the cause of failure to multiply, nor of the eventual degeneration of lengthening bacilli. 


\section{Alterations to the medium}

Many additions were made to the present medium in the hope of obtaining division and multiplication of the bacilli, or a further delay in their degeneration, but these additions, among which was mycobactin (the growth factor for Mycobacterium johnei), were ineffective both at neutrality and in the acid $\mathrm{pH}$ range optimal for lengthening. Substitution of other carbon sources for sucrose, in high or low concentrations (e.g. glucose (Hart \& Valentine, 1960), sorbose or erythritol) gave no advantage. Omission of the sucrose altogether usually decreased the degree of elongation, though not much, but the results were then less regular and uniform. Omission of glycerol led to a much more pronounced diminution in elongation. On the other hand, some elongation (at $\mathrm{pH} \mathrm{6.2)} \mathrm{still} \mathrm{occurred} \mathrm{(both} \mathrm{with} \mathrm{well-}$ washed tissue-culture bacilli and with liver-contaminated bacilli from mice) when the asparagine and Casamino acids were omitted, leaving salts, glycerol, albumin, sucrose, i.e. a mixture rather like the buffer mixture with glycerol (p. 47) and giving similar results.

\section{Results in other media}

A few conventional media were tested for their capacity to promote the lengthening of Mycobacterium lepraemurium. These included Hedley Wright broth, glycerinated broth, and Hanks's basal salt solution with human cord serum. At about $\mathrm{pH} 7$ and 6 , and both with and without sucrose, the bacilli degenerated within a few weeks without obvious lengthening.

\section{The effect of isoniazid}

As is well known, isoniazid suppresses the in vitro multiplication of Mycobacterium tuberculosis; this substance at $1 \mu \mathrm{g} . / \mathrm{ml}$. also completely inhibited the elongation of $M$. lepraemurium at $\mathrm{pH} 6 \cdot 0-6 \cdot 8$. On the other hand, a substrain obtained from an infected mouse and which showed isoniazid resistance in vivo required $25 \mu \mathrm{g}$. isoniazid/ml. for complete inhibition (Hart et al. 1962b).

\section{Total count of acid-fast bacilli}

The possibility of significant changes in the total population of acid-fast bacilli was examined by Dr R. J. W. Rees (method of Hart \& Rees, 1960). The counts were made immediately after inoculation into the medium and also after incubation for 17 days at $\mathrm{pH} 7 \cdot 0$ and at $\mathrm{pH} 6 \cdot 0$. About 80 bacilli were counted in each case, sufficient to detect almost certainly $(P=0.001)$ a change of $50 \%$ or more in the population. In fact, the counts diminished slightly from $1.7 \times 10^{7} / \mathrm{ml}$. initially to $1.5 \times 10^{7} / \mathrm{ml}$. $(\mathrm{pH} 7 \cdot 0)$ and $1 \cdot 4 \times 10^{7} / \mathrm{ml}$. $(\mathrm{pH} 6 \cdot 0)$ after 17 days, but the differences were not significant $(P>0 \cdot 15)$. Almost certainly, therefore, any increase or decrease in the population during the period of maximum bacillary elongation was less than $50 \%$ and consequently unimportant or non-existent.

\section{DISCUSSION}

Gross elongation of the bacilli of many bacterial species in vitro has been frequently described, the common factor being a change in the physical or chemical environment unfavourable enough to prevent multiplication (division) while still permitting 
growth. Mycobacteria are no exception, e.g. Mycobacterium johnei in culture medium containing minimal concentrations of its growth factor mycobactin (Hart, 1958) and $M$. tuberculosis in medium made toxic by urea (Hart, unpublished) or when incubated in certain buffer mixtures (see below). There would be little point in describing elongation in $M$. lepraemurium in a cell-free medium were it not that multiplication has not been achieved for this species in any such medium. Consequently, growth in the mass and length of $\boldsymbol{M}$. lepraemurium bacilli may be an advance towards the possibility of obtaining complete in vitro cultivation; and, unlike the case with other bacteria, the physical and chemical conditions required for maximum elongation can be a guide to those most favourable for this organism.

That the elongation described represents an active vital process and not a passive stretching, or a mere accumulation of material from the medium, is supported by the present evidence-in particular, the gradual progress to a doubling of length in about the time required for one generation cycle in living mice or rats or in fibroblast cultures, namely 7-14 days (Hilson \& Elek, 1957; Rees \& Garbutt, 1962), the suppression of the process by low concentrations of isoniazid, and the failure of isoniazid to do so with a substrain which was isoniazid-resistant in vivo (Hart et $a l .1962 b)$.

Although the bacillary preparations from mice contained some liver material, the ability of the bacteria to lengthen after treatment with sodium hydroxide (which would have digested any whole liver cells still present and removed most of the cell fragments) appears to exclude any analogy with the cell-micro-organism association of tissue culture. On the other hand, the small amounts of residual tissue may have made a nutritional contribution towards the growth.

Elongation of Mycobacterium lepraemurium can be observed as a normal process within the host cells in the initial phase of slow multiplication in progressive murine leprosy infection in mice (Hilson \& Elek, 1957; Chang, 1960; Hart et al. $1962 a$ ) and in monocytes maintained in vitro (Chang, 1961). We have noted abnormal elongation in a minority of the population of the slow-growing $M$. johnei in cultures in or near foci of multiplying short bacilli. However, the extracellular lengthening which we can now obtain with $M$. lepraemurium is far more striking, in that almost all the bacilli are affected, most of them finally reaching three to five times their initial lengths. This abnormal elongation, terminated eventually by degeneration, is presumably a consequence of inability to divide. We have observed a possibly analogous, though less marked, elongation without obvious multiplication in $M$. tuberculosis incubated for several weeks at $37^{\circ}$ in phosphate buffer $(\mathrm{pH} 6 \cdot 0)$ containing albumin and sucrose (a mixture which had given some lengthening of $M$. lepraemurium if glycerol was added, see p. 47); the $M$. tuberculosis bacilli remained short in buffer alone.

The present medium was developed from the Dubos-type formula (without Tween 80), but has a much higher content of amino acids, a high concentration of sucrose, and an acid $\mathrm{pH}$ value (about $\mathrm{pH}$ 6.2). None of the limited number of other media so far tested has given similar results either at neutral or at acid $\mathrm{pH}$ values, with or without sucrose. On the other hand the sucrose, while beneficial in the present medium (optimum about $10 \%$; Hart \& Valentine, 1960), is not essential for the bacillary elongation; consequently the mode of its action in such high concentration is perhaps not of particular interest. Of the other constituents of the 
present medium, glycerol appears to be important for obtaining elongation, but the role of the asparagine and Casamino acids is less certain, since their omission still allowed some lengthening to occur with organisms from infected mouse liver and also with well-washed tissue-culture bacilli. However, the relatively small amount of nitrogen required for growth could have been provided under these conditions by remnants of liver cells or tissue-culture fibroblasts in the preparations, by the albumin, by the autolysis of bacterial cells, or even from the air as has been suggested to explain a multiplication of Mycobacterium tuberculosis in a 'nitrogen-free' medium (Hedgecock \& Costello, 1962).

The narrow range of $\mathrm{pH}$ values for optimum elongation $(\mathrm{pH} 6 \cdot 0-6 \cdot 4)$ was less

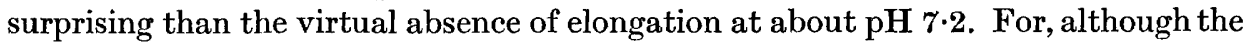
optimum range for multiplication of Mycobacterium tuberculosis has been reported to be in the range pH 6.0-6.5 (Bekierkunst, 1957; Hedgecock \& Costello, 1962), both this species and the more exacting $M$. johnei give profuse yields when cultivated at neutrality; moreover, the elongation of $M$. tuberculosis, mentioned above, was observed at $\mathrm{pH} \mathbf{7 \cdot 0}$, also.

The only method of testing chemotherapeutic agents in a murine leprosy infection is in vivo, or, latterly, in tissue culture. Complete inhibition of elongation of bacilli of Mycobacterium lepraemurium by isoniazid suggests that the doubling or more of mean length which occurs in the first 1-2 weeks of incubation in the present medium without the drug, and which is easily appreciated in the light microscope, could be used as a means for a preliminary assessment in vitro of the activity of potentially antileprosy agents for use in man; this possibility is being investigated. However, it does not necessarily follow that this bacillary elongation, since it is not accompanied by division, can provide information relevant to activity against a progressive infection in the animal body.

We are much indebted to Dr R. J. W. Rees for providing the bacillary suspensions and for his advice and encouragement. We also thank Dr J. Mandelstam for advice on certain biochemical points. A criticism by Professor D. G. Evans suggested an additional experiment and we are grateful to him.

\section{REFERENCES}

Bekierkunst, A. (1957). The effect of $\mathrm{pH}$ of the medium on the growth of tubercle bacilli. Schweiz. Z. Path. Bakt. 20, 312.

Chang, Y. T. (1960). Changes in the length of Mycobacterium lepraemurium in the evolution of murine leprosy in mice. Amer. Rev. Resp. Dis. 82, 409.

Chang, Y. T. (1961). The mouse macrophage as host cell for Mycobacterium lepraemurium. Trans. Symposium on Research in Leprosy (Baltimore), p. 118. Washington: Leonard Wood Memorial.

Dubos, R. J. \& Davis, B. D. (1946). Factors affecting the growth of tubercle bacilli in liquid medium. J. exp. Med. 83, 409.

EdDy, B. E. (1937). Attempted cultivation of Mycobacterium leprae. Int. J. Leprosy, 5, 31.

Garbutt, E. W., Rees, R. J. W. \& BarR, Y. M. (1962). Growth of Mycobacterium lepraemurium maintained in cultures of rat fibroblasts. J. gen. Microbiol. 27, 259.

Gray, C. T. (1952). The respiratory metabolism of murine leprosy bacilli. J. Bact. 64, 305.

HART, P. D'ARcy (1958). A mycobactin-containing liquid medium for the study of Mycobacterium johnei. J. Path. Bact. 76, 205. 


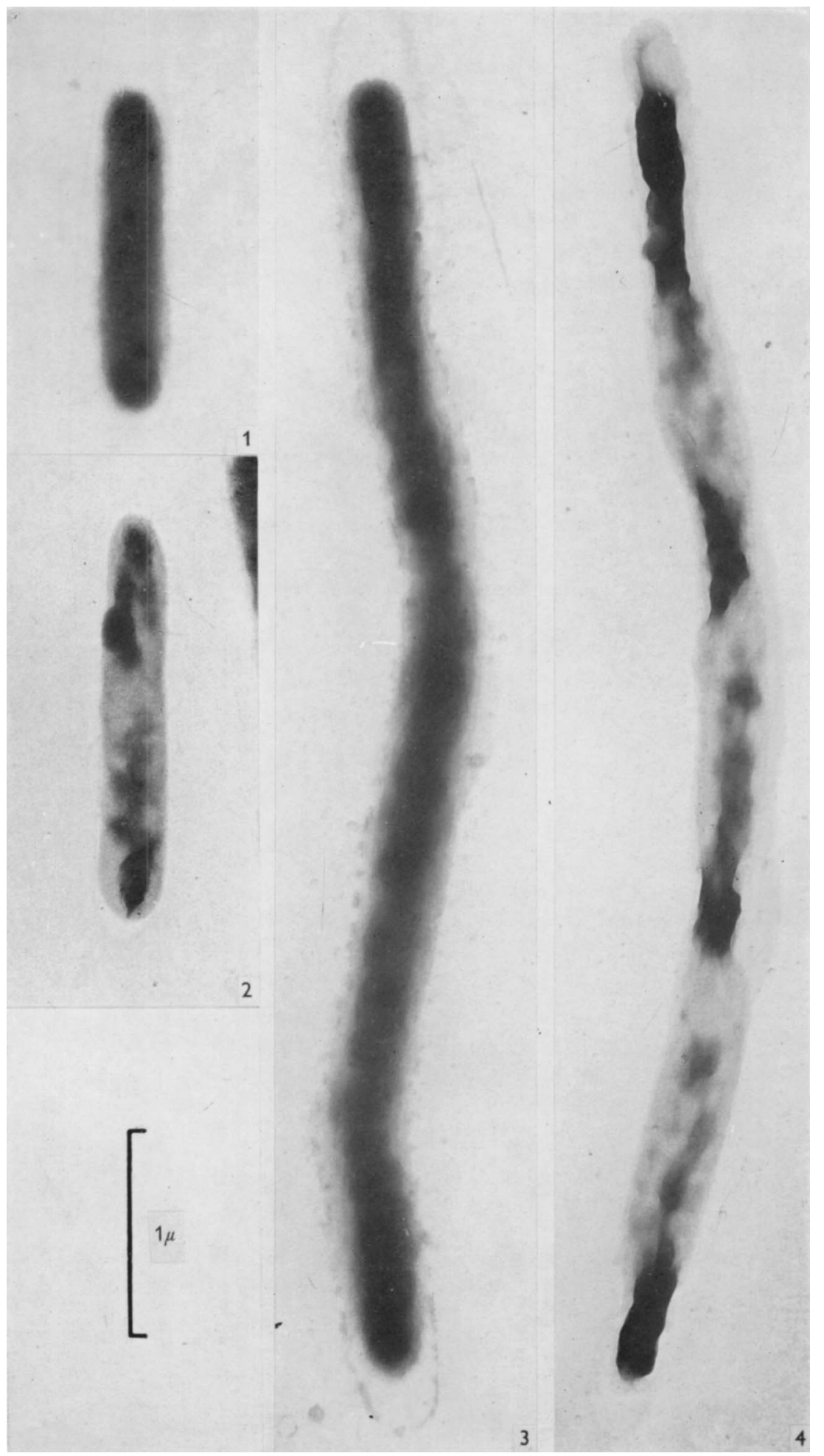


Journal of General Microbiology, Vol. 32, No. 1

Plate 2

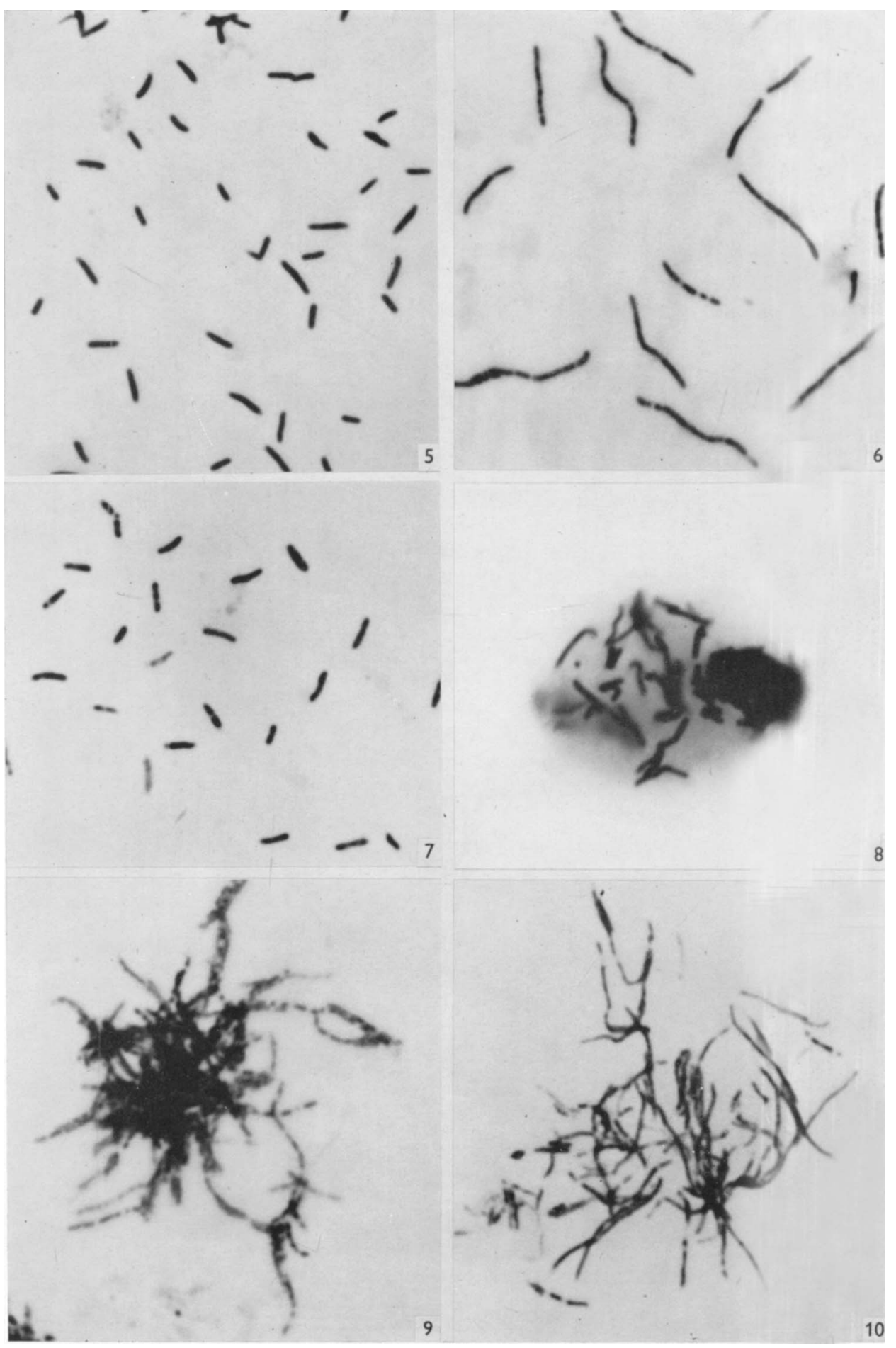

P D'ARCY HAR'T AND R. C. VALENTINE 
Hart, P. D'Arcy \& Rees, R. J. W. (1960). Effect of Macrocyclon in acute and chronic pulmonary tuberculous infection in mice as shown by viable and total bacterial counts. Brit. J. exp. Path. 41, 414.

Har'T, P. D'Arcy, Rees, R. J. W. \& Valentine, R. C. (1962a). The length of Mycobacterium lepraemurium recovered from different animal species and tissues after experimental infection. J. Path. Bact. 83, 153.

Hart, P. D'Arcy, Rees, R. J. W. \& Valentrne, R. C. (1962b). Isoniazid resistant and dependent strains of Mycobacterium lepraemurium studied in vivo and in vitro. J. Path. Bact. 84, 105.

Hart', P. D'Arcy \& Valentine, R. C. (1960). Elongation of a leprosy bacillus (Mycobacterium lepraemurium) in a cell-free medium. Nature, Lond. 185, 58.

Hedgecock, L. W. \& Costello, R. L. (1962). Utilization of nitrate by pathogenic and saprophytic mycobacteria. J. Bact. 84, 195.

Hilson, G. R. F. \& Elek, S. D. (1957). Intratesticular multiplication of Mycobacterium. lepraemurium in normal and suramin-treated animals. Int. J. Leprosy, 25, 380.

McFadzean, J. A. \& Valentine, R. C. (1959). The value of acridine orange and of electron microscopy in determining the viability of Mycobacterium lepraemurium. Trans. Roy. Soc. trop. Med. Hyg. 53, 414.

Nicolay, N. DE (1585). The Navigations into Turkie, p. 33. Transl. T. Washington. London: T. Dawson.

REes, R. J. W. \& Garbutt, E. W. (1962). Studies on Mycobacterium lepraemurium in tissue culture. I. Multiplication and growth characteristics in cultures of rat fibroblasts. Brit. J. exp. Path. 43, 221.

Rees, R. J. W. \& VAlentine, R. C. (1962). A modified Ziehl-Neelsen staining method for identifying dead Mycobacterium lepraemurium. Int. J. Leprosy (in the Press).

VALEntrne, R. C. (1962). Quantitative electron microscopy of leprosy bacilli. Brit. med. Bull. 18, 242.

\section{EXPLANATION OF PLATES}

\section{Plate 1}

Electron microscope pictures of Mycobacterium lepraemurium before and after incubation $(\times 27,000)$.

Fig. 1. A normal bacillus from infected mouse liver.

Fig. 2. A bacillus after incubation for 28 days in phosphate buffer. A typical degenerate appearance.

Fig. 3. A bacillus after incubation for 14 days in the medium at pH 6.2. It has lengthened without yet showing a degenerative appearance.

Fig. 4. A bacillus after lengthening, followed eventually by an appearance typical of degeneration.

Plate 2

Light microscope pictures (Ziehl-Neelsen stain) of Mycobacterium lepraemurium before and after incubation in the medium $(\times 1900)$.

Fig. 5. Normal bacilli obtained from infected mouse liver. The organisms are well dispersed and predominantly single. They are homogeneously stained.

Fig. 6. Similar bacilli after incubation for 17 days at $\mathrm{pH} 6 \cdot 2$. They are long and many have a beaded appearance.

Fig. 7. Similar bacilli after incubation for 17 days at $\mathrm{pH} \mathbf{7 \cdot 4}$. They have not lengthened and many are unevenly stained.

Fig. 8. Normal bacilli in tissue culture fibroblasts.

Figs. 9, 10. Similar bacilli after incubation for 14 days at $\mathrm{pH} 6 \cdot \mathbf{1}$. The fibroblasts have largely autolysed, the organisms are long and some appear beaded. 